Motrivivência Ano XXII, No 34, P. 136-155 Jun./2010

DOI:10.5007/2175-8042.2010n34p136

\title{
DIALOGISMO, DECODIFICAÇÃO E MARKETIN DIGITAL INTERATIVO EM TORNO DAS PRÁTICAS CORPORAIS NO FESTIVAL ON-LINE DE VÍDEOS OLYMPIKUS.MOV
}

Marcos Roberto Godoi ${ }^{1}$

\begin{abstract}
Resumo
O objetivo deste trabalho foi compreender os significados associados as práticas corporais nos vídeos do festival OLYMPIKUS.MOV, e também, analisar a recepção/interação de internautas sobre estes vídeos. A metodologia consistiu na descrição dos vídeos, na seleção de comentários

e na sua posterior análise com base na concepção dialógica da linguagem de Mikhail Bakhtin e nos tipos de decodificação de Stuart Hall. Pudemos concluir que houve uma grande diversidade de práticas corporais e de significados relacionados às elas
\end{abstract}

\begin{abstract}
The aim was to understand the meanings associated bodily practices in the videos of the festival OLYMPIKUS.MOV, and also analyze the reception/interaction Internet users on these videos. The methodology consisted the description of the videos, the selection of comments and further analysis based on the notion of dialogic language of Mikhail Bakhtin and the types of decoding Stuart Hall. We concluded that there was a large range of bodily practices and meanings related to them
\end{abstract}

1 Licenciado em Educação Física (1999) e Mestre em Estudos da Linguagem (2006) pela UFMT. Professor da Rede Pública Municipal de Cuiabá-MT (2000-2009), professor do Centro Universitário de Várzea Grande (2003-2008) e da FEF UFMT (2008-2009). Membro do grupo de pesquisa Corpo, Educação e Cultura COEDUC UNEMAT. Secretário adjunto da Secretaria Estadual do CBCE-MT. Contato:mrgodoi78@hotmail.com. 
nos vídeos. A recepção/interação dos internautas estabelece um diálogo de critica, congratulação, sugestivo e questionador sobre os vídeos.

Palavras-chave: práticas corporais. marketing digital interativo. dialogismo. decodificação.

\section{Introdução}

Nas sociedades contemporâneas, cada vez mais circulam discursos, imagens e sons numa velocidade estonteante, um parte considerável destes, versam sobre os diferentes tipos de esportes, ginásticas, danças, lutas e outras expressões da cultura corporal. Segundo Betti (2009), as mídias transmitem muitas informações sobre a cultura corporal de movimento para um grande número de pessoas, inclusive os alunos de Educação Física. Tais informações estão presentes na TV, em jornais, peças publicitárias, sites da Internet. Senão no plano da prática ativa, no plano do consumo de informações e imagens, a cultura corporal de movimento tornou-se publicamente partilhada.

De acordo com Pires (2003), as práticas corporais da cultura de movimento, especialmente as com potencial de serem espetacularizadas e mercadorizadas, passam a integrar o discurso in the videos. Reception/interaction Internet provides a critical dialogue, congratulation, and suggestive questioning on the videos.

Keywords: bodily practice. interactive digital marketing. dialogism. decoding.

midiático, servindo tanto de veículo como de objeto de consumo. É deste campo, qual seja da cultura e da mídia, que a Educação Física recolhe e trata didaticamente as práticas e os conhecimentos que são transformados em conteúdos de suas múltiplas intervenções profissionais. Assim, por via indireta a mídia vem assumindo crescente importância nos saberes/fazeres da cultura de movimento.

Com o crescimento da pesquisa em mídia e Educação Física, diversos estudos têm surgido no âmbito das análises de produtos da mídia, com preocupação constante na análise de produtos televisivos ou dos meios impressos. Porém, quando se pensa nas possibilidades de investigação no âmbito da Internet as análises ainda são incipientes (MENDES et. al., 2009).

No que tange a Internet, é importante destacar que pessoas conectadas em qualquer parte do globo tanto podem acessar textos, imagens, sons e vídeos, quanto produzir e divulgar suas produções 
através de blogs, do YouTube ou de outros sites interativos. Conforme Betti:

é preciso considerar que o cenário contemporâneo complexificou sobremaneira, em especial pelo acesso facilitado às tecnologias que permitem a todos serem autores de materiais audiovisuais. A possibilidade de associar tecnologias coloca à disposição no mercado, por preços relativamente acessíveis, câmeras fotográficas e celulares com filmadora, além das próprias filmadoras portáteis. Há também disponíveis na Internet softwares de edição de vídeos gratuitos, de fácil acesso e manuseio. Somado a isto, cada um desses novos autores encontra na Internet imensa facilidade em veicular e distribuir seus produtos pela rede, especialmente em sites como o YouTube (BETTI, 2009, p. 279-280).

Neste sentido, o tema desta pesquisa baseia-se nos significados das práticas corporais nos vídeos do festival OLYMPIKUS.MOV promovido pela marca de produtos esportivos Olympikus no ano de 2009 -, e na recepção/interação dos internautas com estes vídeos no site do festival. Com base neste tema, levantamos as seguintes perguntas de pesquisa: Quais são as práticas corporais retratadas nos vídeos do festival? Quais sentidos são associados a elas nos vídeos? Como os usuários do site interagem sobre os vídeos? Em decorrência, os objetivos da pesquisa foram: compreender quais são as práticas corporais presentes nos vídeos e os significados associados a elas; e analisar a recepção/interação de internautas com os discursos destes vídeos.

Preferimos o termo práticas corporais a esporte ou atividade física, pois entendemos que este é um conceito mais amplo. De acordo com Carvalho (2006), as práticas corporais são elementos da cultura corporal dos povos, dizem respeito ao homem em movimento, à sua gestualidade, aos seus modos de se expressar corporalmente. Elas agregam as mais diversas formas do ser humano se expressar por meio do corpo e contemplam duas racionalidades: a ocidental (ginásticas, modalidades esportivas e caminhadas podem ser exemplos) e a oriental (tai-chi, ioga e lutas, entre outras). A toda prática corporal são atribuídos valores, sentidos e significados. Dessa constatação decorre que há sentido praticar ginástica aeróbia para algumas comunidades, mas não para outras.

Sobre o funcionamento do festival de vídeo, o link "o festival", apresenta a seguinte explicação: "Que tipo de inspiração coloca as pessoas em movimento? O desejo 
de ser mais saudável, mais bonito. A vontade de ser mais rápido, mais forte. O desejo de vencer os próprios limites, um adversário ou a vontade de se divertir, simplesmente. Com certeza tudo isso e muito mais" (OLYMPIKUS, 2009). Além disso, há informações sobre as inscrições, que podiam ser feitas por uma ou mais pessoas. $\mathrm{O}$ foco do vídeo tinha que ser sobre o tema esporte mais o conceito "inspire-se" e ter duração entre 1 a 5 minutos. Os vídeos ficaram disponíveis no site da Olympikus onde recebia votos e comentários e no canal desta mesma marca esportiva no YouTube. Os autores ganharam kits de produtos da marca, sendo que os dez vídeos mais votados (5 pelo júri técnico e 5 pelo júri popular) fizeram parte da lista dos candidatos escolhidos e entraram em um DVD da Olympikus. No final do festival, uma comissão julgadora escolheu o melhor vídeo, que ganharia de prêmio a inscrição nos principais festivais de cinema do Brasil durante um ano, com todos os custos pagos pela Olympikus.

No site do festival estava disponível o regulamento do festival $^{2}$ e a descrição da premiação. Há ainda links: "fórum do festival", "material de apoio" com claquete, lettering Inspire-se e logos Olympikus, todos obrigatórios na produção dos vídeos. Há também um link "contato", com possibilidades de contato por msn, e-mail, twitter e orkut. No link "assista aos vídeos", há um espaço para comentários dos vídeos e local para realizar a votação, indicando a quantidade de estrelas que o vídeo merecia, de uma a cinco. Por último, o link "conheça os vencedores", com os cinco melhores vídeos segundo seleção do júri popular e os cinco melhores segundo seleção do júri técnico. De acordo com o vídeo de encerramento do festival, foram 83 vídeos inscritos, 37.139 visitas no site em pouco mais de um mês, 133.297 minutos de material assistido pelo público.

No que tange a metodologia, ela consistiu no levantamento das práticas corporais representadas nos vídeos do festival e na categorização temática dos mesmos. Após selecionamos um corpus de análise menor, com cinco vídeos e vinte e dois comentários relacionados aos vídeos. O referencial teórico de análise foi baseado na concepção dialógica da linguagem de Mikhail Bakhtin (1997 e 2003), e nas categorias de decodificação de Stuart Hall (2006): código dominante ou

2 Quando consultamos o site do festival o regulamento tinha sido retirado do mesmo. 
consensual, código negociado e código oposicionista. Estas categorias serão explicadas no decorrer da análise. No entanto, cabe destacar desde agora o conceito de dialogismo. Bakhtin (1997) entende que a realidade fundamental da língua é constituída pelo fenômeno da interação verbal. No entanto, concebe o diálogo não no sentido estrito do termo como comunicação em voz alta, de pessoas colocadas face a face, ainda que esta seja uma das mais importantes formas da interação verbal. Ele compreende a palavra "diálogo" num sentido mais amplo, como toda comunicação verbal, de qualquer tipo que seja. Neste sentido, um bilhete familiar, uma carta, um e-mail, um livro, uma poesia, um filme, um programa de TV ou uma propaganda também podem diálogos. Segundo este estudioso, qualquer enunciação por mais completa que seja, constitui apenas uma fração de uma corrente de comunicação verbal ininterrupta, referente à vida cotidiana, à literatura, ao conhecimento, à política etc.

\section{Sobre convergências midiáticas e marketing digital interativo}

É cada vez mais comum ouvirmos falar de convergência de mídias ou convergência midiática.
De acordo com Costa (2009, p. 2), "hoje podemos entender convergência midiática como um processo, a princípio técnico, que consiste na capacidade de trânsito de conteúdos midiáticos por diversos canais comunicativos, ampliando a capacidade responsiva daqueles que fruem tais conteúdos". Este fenômeno pode ser reconhecido na mass media, como a televisão, o jornal e a internet, mas também em ferramentas como câmeras digitais e telefones celulares, capazes de fazer circular informações em formatos compatíveis com os meios acima. O que parece mais evidente é que a lógica dos meios de comunicação está mudando. Pelas lentes do digital, a instância dos receptores de mensagens se fortalece no circuito comunicativo, que paulatinamente assumem um papel de co-responsabilidade na geração de conteúdos midiáticos (COSTA, 2009). No universo das práticas corporais, podemos citar o quadro "Bola murcha e bola cheia" do programa Fantástico da Rede Globo de Televisão, no qual telespectadores enviam vídeos de jogadas desastrosas e espetaculares de futebol postando os mesmos no site ligado a programa.

Oliveira (2010) distingue três formas de convergências midiáticas: convergência entre mídias de função massiva; convergência entre mídias de função pós-massiva; 
e convergência mista. A primeira continua com as características da transmissão de pacotes de informação para uma grande massa, tratada homogeneamente, com raro espaço para opinião. Esta convergência pode ser visualizada quando ao fim do telejornal o apresentador convida os espectadores para mais informações no site personalizado do programa; quando revistas de televisão convidam o espectador para recortar a receita de culinária que estará no jornal impresso do dia seguinte; ou ainda entrevistas que tem curta duração na televisão, mas que são expandidas no programa de rádio do mesmo grupo de comunicação.

Já a convergência pósmassiva, segundo este autor, pode ser visualizada em blogs e em sites de conteúdo audiovisual como o YouTube, Vimeo e DailyMotion. Apesar da influência estilística das mídias tradicionais, a forma de distribuição e relação com o receptor final nestas mídias é de função pósmassiva: não há interesse direto de lucro, há espaço reservado para comentários, o foco está em nichos específicos de interesse e geralmente estão registrados sobre licenças Creative Commons ${ }^{3}$, com apenas alguns direitos reservados.

A função mista é baseada na fusão das duas categorias anteriores. Com a popularização das mídias mais sociais, como blogs e podcasts ${ }^{4}$, tem sido cada vez mais comum as mídias de função massiva se conectarem a essas possibilidades. Como por exemplo, os grupos de comunicação que investem na produção de seus próprios portais e passam a divulgar blogs de jornalistas e artistas ligados a este grupo, ou aplicativos para compartilhar a informação a redes sociais como Facebook, Twitter, Digg, Stumbleupon (OLIVEIRA, 2010).

Deacordo com Costa(2009), uma das características da Web 2.0. ${ }^{5}$ é o compartilhamento cooperativo de

3 Creative Commons é uma organização não governamental sem fins lucrativos localizada em São Francisco, Califórnia, nos Estados Unidos, voltada a expandir a quantidade de obras criativas disponíveis, através de suas licenças que permitem a cópia e compartilhamento com menos restrições que o tradicional todos direitos reservados. Para esse fim, a organização criou diversas licenças, conhecidas como licenças Creative Commons (WIKIPÉDIA).

4 Podcast é o nome dado ao arquivo de áudio digital, geralmente em formato MP3 ou AAC (este último pode conter imagens estáticas e links), publicado através de podcasting na internet e atualizado via RSS. Também pode se referir a série de episódios de algum programa quanto à forma em que este é distribuído. A palavra é uma junção deiPod ou de "Personal On Demand" (numa tradução literal, algo pessoal e sob demanda) e broadcast (transmissão de rádio ou televisão). O podcast em vídeo chama-se "videocast", geralmente em arquivo formato MP4 (WIKIPÉDIA).

5 O termo Web 2.0. surgiu como designação de uma espécie de ressurgimento da Internet após ao "estouro da bolha" das empresas ponto com, o que parecia o fim da Internet segundo previsões pessimistas, resultou na celebração das possibilidades de inclusão dos usuários que a rede oferece. 
conteúdos, essa idéia não se fazia presente na primeira fase dos serviços online. Em seu ambiente, a Web 2.0. permite enfatizar a participação dos usuários. Vários atributos das produções audiovisuais e dos canais de vídeo na Internet partilham dos pressupostos da Web 2.0., como a ênfase na participação, a constante atualização e ampliação dos recursos e funcionalidades disponíveis aos usuários e a integração com outras plataformas da web. Por este prisma é possível entender os processos de produção simbólica em que de um lado, usuários-produtores valem-se das prerrogativas da web 2.0. para promoverem quebras de expectativas no manejo dos gêneros do discurso, enquanto que, de outro, instâncias midiáticas tradicionais mostram maior atenção aos enunciados produzidos pela sua audiência. Keen (apud COSTA, 2009), afirma que as ferramentas participativas na web 2.0. têm sido loteadas pelas grandes indústrias da informação e do entretenimento, deturpando o objetivo original de promover a confluência de opiniões, como alternativa a hegemonia dos mass media, gerando uma pretensa democratização da comunicação. Ainda assim, há uma realidade impensável nas práticas de linguagem há alguns anos: a emergência das redes sociais, o bate-papo instantâneo e as investidas de milhares de videomakers amadores no YouTube e outros dispositivos, rumo a afirmação de uma estética menos canônica dos mass media (COSTA, 2009).

Sobre o impacto deste novo cenário comunicação na publicidade, Coutinho (2007), afirma que a comunicação mercadológica terá que incorporar um elemento a qual está pouco acostumada até agora: a comunicação entre os consumidores e não apenas com os consumidores, tendo a marca como suporte e veículo de interação entre a empresa e seus mercados. Ou seja, não se trata "apenas" de fazer os consumidores comprarem uma marca, mas de se organizarem em torno dela. $\mathrm{O}$ que implica em reconhecer as especificidades que interação entre os consumidores, entre diversos grupos de consumidores e do conteúdo gerado por eles pode ter sobre as marcas. Ou seja, é o marketing buscando os caminhos da interatividade no ambiente virtual da Internet. No entanto, ainda que mudem os meios, a função da publicidade continua sendo a mesma: divulgar e vender produtos e serviços.

\section{Análise e discussão dos resul- tados}

Assistimos a todos os vídeos do festival e realizamos um levantamento das práticas corporais representadas nestes vídeos. Em alguns vídeos mais de uma prática corporal estava presente, mas a maioria tratava de apenas uma prática. Pudemos encontrar também dois vídeos que não aparecia nenhuma 
prática corporal específica, eles promoviam uma reflexão sobre o que seria das práticas corporais sem os participantes. As práticas corporais que mais apareceram nos vídeos foram a corrida $(N=26)$, futebol e skate $(N=11)$, ciclismo $(N=09)$, basquetebol $(\mathrm{N}=07)$, alongamento/ abdominais e caminhada $(\mathrm{N}=6)$, outras modalidades de atletismo além da caminhada e voleibol
$(\mathrm{N}=05)$, dança e ginástica $(\mathrm{N}=04)$, hip-hop/dança de rua, natação, torcida de futebol ${ }^{6}$ e parkour ${ }^{7}(\mathrm{~N}=03)$, outras práticas corporais tiveram uma freqüência de aparição menor. É possível perceber a grande diversidade de práticas representadas nos vídeos (38 práticas diferentes), provavelmente indicando a variedade de práticas corporais do gosto ou do interesse dos produtores.

\section{Tabela 01 - Práticas corporais veiculadas nos vídeos e número de vídeos que apresentam}

\begin{tabular}{|c|c|c|c|c|c|}
\hline $\mathrm{N}=$ & $\begin{array}{l}\text { Práticas } \\
\text { corporais }\end{array}$ & $\mathrm{N}=$ & Práticas corporais & $\mathrm{N}=$ & Práticas corporais \\
\hline 26 & Corrida & 03 & Parkour & 01 & Ginástica Rítmica \\
\hline 11 & Futebol & 02 & $\begin{array}{l}\text { Acrobacias corporais/ } \\
\text { circo }\end{array}$ & 01 & latismo \\
\hline 11 & Skate & 02 & Basquete adaptado & 01 & Judô \\
\hline 09 & Ciclismo & 02 & Bicicross & 01 & Musculação \\
\hline 07 & Basquetebol & 02 & Brincadeiras infantis & 01 & Parapente \\
\hline 06 & $\begin{array}{l}\text { Alongamentos/ } \\
\text { abdominais }\end{array}$ & 02 & Montanhismo & 01 & Patinação \\
\hline 06 & Caminhada & 02 & Motocross & 01 & Rolimã \\
\hline 05 & Atletismo $^{1}$ & 02 & Nenhuma & 01 & Rugby \\
\hline 05 & Voleibol & 01 & Balé & 01 & Surf \\
\hline 04 & Dança & 01 & Capoeira & 01 & $\begin{array}{l}\text { Surf em cima de } \\
\text { bicicleta }\end{array}$ \\
\hline 04 & Ginástica & 01 & Cavalgada & 01 & Wakeboard \\
\hline 03 & $\begin{array}{l}\text { Hip hop/dança } \\
\text { de rua }\end{array}$ & 01 & Educação Física & 01 & Xadrez \\
\hline 03 & Natação & 01 & Gatebol & & \\
\hline 03 & $\begin{array}{l}\text { Torcida de } \\
\text { futebol }\end{array}$ & 01 & Ginástica Aeróbica & & \\
\hline
\end{tabular}

6 Analisando os vídeos pudemos perceber uma intensa mobilidade corporal dos torcedores, a movimentação dos braços, das mãos, do corpo, os gritos de guerra, os movimentos de bandeiras, faixas.

7 Parkour ou l'art du déplacement (em português: arte do deslocamento) é uma atividade cujo princípio é mover-se de um ponto a outro o mais rápida e eficientemente possível, usando principalmente as habilidades do corpo humano. Criado para ajudar a superar obstáculos de qualquer natureza no ambiente circundante, desde galhos e pedras até grades e paredes de concreto, e pode ser praticado em áreas rurais e urbanas (WIKIPÉDIA).

8 Outras modalidades do atletismo além da corrida. 
Interessante observar a aparição de práticas corporais pouco conhecidas e divulgadas na mídia, como por exemplo, o parkour, o gatebol ${ }^{9}$, o rugby, o rolimã, o surf em cima de bicicleta. Esta última prática corporal foi apresentada em um vídeo documentário em que o seu idealizador conta como surgiu a idéia de realizar esta prática corporal.

Conforme Betti (2001), a cultura corporal de movimento alargou-se no mundo contemporâneo, práticas se multiplicam e se pulverizam. Sob o patrocínio da mídia, a denominação esporte passa a designar essa diversidade de práticas, as quais já não mais atendem aos critérios clássicos da Sociologia do Esporte (competição, comparação de desempenhos, busca da vitória ou recorde etc.), fala-se em: prazer, bem-estar, aventura, desafio, natureza, diversão. É exatamente esta diversidade de significados que podemos observar na próxima tabela com a classificação temática dos vídeos.

\section{Tabela 2 - Classificação temática dos vídeos e número de vezes que aparecem nos vídeos}

\begin{tabular}{|l|l|}
\hline $\mathbf{N}=$ & Tema dos vídeos \\
\hline 13 & Pessoas ou bonecos realizando as práticas corporais \\
\hline 12 & Persistência, superação de limites e das adversidades \\
\hline 06 & Dia-a-dia das pessoas e sua relação com as práticas corporais \\
\hline 04 & Sonho, fantasia ou imaginação: fuga do cotidiano agitado \\
\hline 04 & Preocupação ou redução do peso corporal \\
\hline 04 & Significados e benefícios das práticas corporais \\
\hline 04 & Alegria, brincadeiras e práticas corporais. \\
\hline 03 & Romance, uma das pessoas realiza práticas corporais e inspira a outra a realizar \\
\hline 03 & Amizade, integração pelas práticas corporais \\
\hline 03 & Práticas corporais para idosos \\
\hline 03 & Torcidas: união, gritos de guerra e movimentos corporais de torcida de futebol \\
\hline 03 & Liberdade e bem estar \\
\hline 02 & Situação de ensino de alguma prática corporal \\
\hline 02 & Saída do trabalho para realizar as práticas corporais \\
\hline 02 & Integração do corpo e da mente \\
\hline 02 & Esvaziamento dos lugares de práticas corporais e não movimento \\
\hline 02 & Integração com a natureza, conhecimento de novos lugares \\
\hline 02 & Reflete sobre possibilidades de realizar a prática corporal. \\
\hline 02 & Cuidados com a saúde, corpo ou com alguma parte dele. \\
\hline 01 & A mulher e as práticas corporais \\
\hline 01 & Elogio ao esporte amador e a prática desinteressada \\
\hline 01 & Família e sua relação com o esporte. \\
\hline 01 & Estímulo imperativo as práticas corporais \\
\hline 01 & Fuga da cidade para o campo para realizar as práticas corporais \\
\hline 01 & Criação de uma nova prática corporal \\
\hline 01 & Projeto social com práticas corporais \\
\hline 01 & Possibilidade de crianças se tornarem atletas \\
\hline 01 & Solidariedade e estímulo as práticas corporais \\
\hline
\end{tabular}

9 O gatebol surgiu no Japão em 1947. O princípio do jogo consiste em impulsionar a bola com o auxílio de um taco (stick) e fazê-la passar sob três arcos. 
Foram identificados 28 temas diferentes relacionados às práticas corporais. Os temas mais presentes nos vídeos foram: a realização de práticas corporais servindo de inspiração para as mesmas; persistência, superação de limites e das adversidades; e cotidiano das pessoas e suas relações com as práticas corporais. Outros temas aparecem com menor freqüência. Conforme Bakhtin (1997), o tema é um sistema de signos dinâmico e complexo que procura adaptação às condições de um dado momento da evolução. Não há tema sem significação e viceversa. O tema deve buscar apoio em certa estabilidade da significação, do contrário, ele perderia seu elo com o que precede e com o que segue, isto é, ele perderia seu sentido.

Podemos perceber uma verdadeira polifonia de significados relacionados às práticas corporais nos vídeos do festival. O conceito de polifonia originário da obra de Bakhtin, de acordo com Stam (2010, p. 345), "chama a atenção para a coexistên- cia, em qualquer situação textual ou extratextual, de uma pluralidade de vozes que não se fundem numa única consciência, e sim existem em diferentes registros, gerando dinamismo dialógico entre si". Deste modo, os discursos dos vídeos em relação às práticas corporais não expressam somente os significados relacionados à estética e ao corpo perfeito, nem mesmo somente aos resultados de competições, comparação de resultados e busca da vitória ou recorde. Através da classificação temática dos vídeos do festival podemos perceber diferentes significados relacionados às práticas corporais: fuga do cotidiano agitado; alegria, brincadeiras e práticas corporais; romance inspirando as práticas corporais; amizade e integração; liberdade e bem estar e muitos outros.

A seguir vamos descrever cinco vídeos do festival e alguns comentários relacionados a eles postados por internautas que visitaram o site. O primeiro vídeo foi o vencedor do júri técnico.

\footnotetext{
Vídeo "Elton e a bailarina" - 2'50" - Direção Diógenes de Moraes, Roteiro Marjory Corrêa, Produção Marjory Corrêa e Matheus Mombelli, Realização DRAMAZepellin

O vídeo mostra imagens de Elton em seu cotidiano, no metrô, em sua casa, caminhando pelo passeio na cidade, e mais ao final o mostra caminhando na mata e depois escalando uma montanha. Ele diz com voz em off: "Minha história de vida é uma dentre tantas outras histórias de qualquer cidadão brasileiro". Elton e a bailarina. "Trabalho muito e tenho uma vida corrida. Já perdi muito fim de semana, muito sábado e domingo por causa do trabalho que faço. Não tenho o nível superior, minha família é simples e tive que trabalhar desde cedo. Me apaixonei (sic.) por uma pessoa maravilhosa. Uma bailarina, que me fez ver o mundo de uma outra forma. Só que para duas pessoas conviverem em harmonia é fundamental um entender a loucura da outra. Minha história de vida é uma dentre tantas outras histórias de qualquer cidadão brasileiro. Já pensei em desistir de tudo, mas provar para mim que meu sonho vale a pena era maior do que qualquer coisa, o tempo foi passando e do esporte e do lazer eu fiz a minha profissão. Alpinismo industrial. Tudo que tenho é graças as montanhas. Através do esporte mantenho viva duas das maiores inspirações da minha vida. A montanha e a Aline, a minha bailarina". No final Aline está esperando Elton no alto da montanha, eles se beijam. INSPIRE-SE.
} 
Este vídeo gerou 195 comentários no site. A seguir destacamos seis deles:

jaque - 02/11/2009 11:56:55

Achei o vídeo legal pq ele começa com uma ênfase na força de vontade relacionada à batalha da vida e do esporte, mas culmina (e é bem isso mesmo, pq é no pico da escalada) com o atleta se completando com a afetividade. $\mathrm{O}$ que pode ser mais inspirador do que alguém se realizar no trabalho, no lazer e no amor?!

Odilei Medeiro - 03/11/2009 12:19:58

Parabéns a todos, parabéns aos idealizadores desse filme. A história é muito linda e as imagens, nem se fala. O velho Itacolomi mais uma vez eternizado e a homenagem a esse cara que revolucionou o montanhismo e a escalada no Rio Grande do Sul e no Brasil. Um cara que acreditou no seu sonho e transformou a vida de várias pessoas. Uma homenagem mais que justa a esse lindo casal. Parabéns Diógenes, Marjory, Matheus (Zeppelin) e Aline e Elton. Torço para que esse vídeo vença!!!

\section{Ayr Müller Gonçalves - 03/11/2009 02:46:20}

Sou avesso a competições e simplificações no que tange a idéias e criações alheias. Não creio que a vida se resuma em vencedores e perdedores. $\mathrm{O}$ casal em questão é um exemplo de sobreviventes, neste local de tantas incongruências e loucuras, talvez a maior vitória seja a insistência na busca do ser acima do mundo do ter. Ah com relação a ganhar algum prêmio, nem estou interessado, o prêmio maior seria conviver com eles conhecê-los, interagir.

No que tange ao processo de compreensão do discurso do outro, Bakhtin (2003) esclarece que o ouvinte (ou leitor), ao perceber e compreender o significado do discurso ocupa simultaneamente uma posição responsiva ativa em relação a ele: concorda ou discorda (total ou parcialmente), completa-o, aplica-o, prepara-se para usá-lo etc. Essa posição responsiva do ouvinte se forma ao longo de todo o processo de audição (ou leitura) e compreensão. Toda compreensão do enunciado vivo é de natureza ativamente responsiva, embora o grau de ativismo seja bastante diverso.

Podemos perceber que os dois primeiros comentários concordam com a mensagem do vídeo. O comentário de Jaque destaca a força de vontade na vida e no esporte e a realização profissional e na vida afetiva, expressos no vídeo. O co- 
mentário de Odilei parabeniza os idealizadores, faz um julgamento de valor dizendo que a história dos dois é "linda". Toda enunciação compreende uma orientação apreciativa. É por isso que, na enunciação viva, cada elemento contém ao mesmo tempo um sentido e uma apreciação. A significação objetiva forma-se graças à apreciação, pois ela indica que uma determinada significação entrou no horizonte dos interlocutores, tanto o horizonte imediato quanto o horizonte social mais amplo de um determinado grupo social (BAKHTIN, 1997).

Já o comentário de Ayr faz uma leitura crítica da própria competição na vida, do ter em detrimento do ser, valores basilares da sociedade capitalista. Diz ainda que seria muito mais importante conhecer, conviver e interagir com o casal Elton e Fernanda, do que ganhar o prêmio. Deste modo, parece fazer uma "leitura oposicionista" do próprio festival e da sociedade capitalista. Conforme Hall (2006), os receptores podem fazer uma leitura no código dominante, que aceita os conteúdos sem questioná-los; uma leitura dentro do código negociado, no qual questionam partes do conteúdo, mas não questionam a atitude sociopolítica fundamental; ou ainda uma leitura no código oposicionista, na qual o receptor se opõe e discorda fundamentalmente ao conteúdo que é considerado um produto de um determinado sistema social. Vejamos mais três comentários a respeito do primeiro vídeo.

Paulo - 07/11/2009 03:15:57 bom o vídeo. Mas também, realizado pela Zeepelin é fácil, com toda a estrutura de uma das maiores produtoras do país. Acho desleal uma produtora deste porte estar participando neste festival, que devido ao tema e foco abordado deveria estar dando oportunidade para novos talentos!!!! fica ai minha crítica! Abraços

elton - 07/11/2009 06:55:16

Paulo o video foi feito com uma camera de video, a Zeppelin NÃO fez o video. E SIM a DRAMA. Discordo de VC Paulo. Elton.

\section{Angelita Karpisnki - 11/11/2009 01:01:11}

só para os q estão reclamando, pq o video ficou bom de mais: no regulamento PARTICIPAÇÃO $1.1 \ldots$ profissionais ou amadores ...... é bom ler o regulamento, acho q isto responde a pergunta de Paulo e Bernardo. No mais, amo muito esse video e seria uma grande pena se ele não ganhar.

Podemos perceber que o comentário do Paulo reconhece que 
o vídeo é bom, mas questiona e critica o fato de ele ser realizado pela produtora Zeppelin, gerando uma situação desleal diante dos outros competidores. Deste modo, Paulo parece fazer uma "leitura negociada", concorda que o vídeo é bom, mas discorda do aparato (recursos técnicos) com o qual foi produzido. Elton, o protagonista do vídeo esclarece que o vídeo foi feito com uma única câmera de vídeo e que foi a Drama que realizou as filmagens.
Angelita lembra que o regulamento do festival previa a participação de profissionais ou amadores, termina defendendo a vitória do vídeo. Ainda que esta situação estivesse prevista no regulamento (amadores e profissionais), realizar um festival de vídeo e colocar amadores para concorrer com profissionais parecenos injusto.

A seguir vamos descrever o vídeo que ficou em segundo lugar na opinião do júri técnico.

Vídeo "Fibra" - 1'12" - Direção, roteiro e produção Daniel Bacchieri, Produção executiva Estação Elétrica Filme e Vídeo

O vídeo mostra o depoimento de Joe, um atleta amador. As imagens foram captadas numa pista de atletismo. Em alguns momentos a câmera o focaliza treinando e em outros ele dando a entrevista. FIBRA - "Eu gosto de fazer atletismo, né. Eu sempre fiz atletismo desde os meus dezesseis anos". Corre desde os 16 anos. "... nos Jogos Escolares, tentei futebol até os dezoito. Eu trabalho 12 horas num dia, no outro dia eu tenho a folga né". Trabalha 12 horas por dia. "Mas na verdade eu não folgo porque eu tenho uma maquinazinha de cortar grama, uma roçadeira, nos dias de folga eu vou fazer uns trabalhos de jardinagem e finais de semana eu faço trabalho de arbitragem de futebol né". Atleta, jardineiro, juiz de futebol. "Então é sempre na correria. O tempo que meu corpo tá, que eu acho que eu estou descansado, que aquele horário mais serve para mim treinar eu faço treino. Eu procuro fazer sempre no primeiro horário da manhã pra ficar livre né" Treino 5:30 a.m. "... cinco e meia, sete horas da manhã. Tem semanas que eu chego a rodar 200 km por semana". Corre $200 \mathbf{k m}$ por semana. "A alimentação é o que tem, o arroz, o feijão, uma massa". Dieta, feijão e arroz. "Quando dá para botar uma granola, aveia. Meu nome é Joe Luís Machado de Oliveira, eu tenho 39 anos, eu sou gari". INSPIRE-SE

O segundo vídeo teve 22 comentários postados no site. Selecionamos três para análise:

Samuel Moreira - 23/09/2009 06:04:56

desfecho surpreendente

Diones - 26/09/2009

08:40:22

Você é exemplo do típico brasileiro batalhador, que luta pela sobrevivência. E a mim cabe humildemente parabenizar e dizer que siga em frente, servindo de inspiração pra muitos. Parabéns

\section{Pedro de Filippis - 04/11/2009 03:42:51}

Curti muito! A trilha é muito boa também, parabéns!

De uma maneira geral, os comentários sobre este vídeo foram 
menos extensos. Samuel destaca o desfecho do vídeo, achando o mesmo "surpreendente", no caso o fato de o protagonista ser gari. O vídeo mostra a história de um brasileiro simples, que realiza trabalhos extras para complementar a renda, é atleta e sobrevive com pouco. Diones destaca em seu comentário que Joe é um típico brasileiro batalhador na luta pela sobrevivência, que serve de inspiração para muitos. Para Bakhtin (2003, p. 297), "os enunciados não são indiferentes entre si e nem se bastam cada um a si mesmos; uns conhecem os outros e se refletem mutuamente uns aos outros". Deste modo, o comentário de Diones dialoga com uma série de propagandas que circularam em 2004, cujo slogan era "O melhor do
Brasil é o brasileiro. Sou brasileiro e não desisto nunca", promovidas pela Associação Brasileira de Anunciantes (ABA) com o intuito de melhorar a auto-estima do brasileiro. Essas propagandas mostraram brasileiros comuns e famosos que se destacaram por superar situações difíceis no campo pessoal e profissional, e assim, eram dignos de serem exemplos para o povo brasileiro. Pedro destaca que curtiu muito o vídeo e a trilha sonora. Em termos das leituras dentro do código de decodificação proposto por Hall (2006), os três comentários fazem uma leitura dominante do vídeo.

A seguir a descrição do vídeo que ficou em terceiro lugar no júri técnico.

Minha calça inspiradora - 1'43" - Direção, roteiro e produção Henrique Schelp

O vídeo é uma animação feita de rabiscos. Aparece a logo da Olympikus e depois o texto Olympikus apresenta: minha calça inspiradora. Com Davis dos Santos, baseado em fatos reais. Aparece um bonequinho feito de riscos, ele dá tchau e sorri. Depois ele engorda, sua barriga fica proeminente. Ele olha pra barriga, se assusta, fica bravo, triste e chora. Aparece do lado dele '167 Kg'. Ele olha para o peso, sorri, coloca as mãos para trás e vai se deslocando para o lado do peso. Dá um chute e manda o peso para longe. O peso volta e bate na cabeça dele. Ele coça a cabeça. Ele pega uma calça grande, olha para ela e depois veste a mesma. Olha para a mesma, prende a respiração e fecha o botão. Mas o botão estoura, a calça cai. Ele olha para o chão, sorri e esconde suas região genital. Depois ele tem uma idéia, começa a fazer alongamentos e caminhar, depois de um tempo seu peso diminui e ele volta a como era antes. Ele sorri e chega até um pódio, que tem um troféu esperando por ele. Ele sobe, pega o troféu e levanta para o alto, estouram vários fogos de artifício. Depois ele coloca o troféu em uma mesa, lá tem outros troféus, medalhas e um quadro com sua calça grande pendurada na parede e um tênis Olympikus sobre a mesa. Aparece em close um tênis Olympikus dando uma pisada e a inscrição INSPIRE-SE.

Este vídeo ocasionou 35 comentários dos internautas. Abaixo destacamos três:
Flávia de Oliveira Ribeiro 24/10/2009 10:31:47

Dentro da proposta da marca atendeste a expectativa de uma 
imagem próxima ao consumidor, que no dia a dia possui movimentos de superação e de vitórias. Além da montagem criativa, carregada de humor e identidade pode-se perceber a mesagem de forma clara e objetiva. Parabéns pelo trabalho, uma pequena mostra de tantos outros que, com certeza, virão. Um grande abraço e muito sucesso! Beijos...

\section{jhonny bonilla - 16/11/2009 01:29:33}

Parabens, muito criativo e convincente, vou comprar o meu material esportivo, pelo jeito a olimpikus resolvera o meu problema!!!! abraço Jhonny

protasio moraes - 22/11/2009 03:57:02

baita sacada! simples, direto, objetivo, inteligente e engraçado! excelente!

Os três comentários destacados, e mesmo os outros que estão no site fazem uma "leitura dominante" do vídeo, segundo a classificação de Hall (2006). Os comentários destacam a linguagem direta, objetiva, clara e o tom humorístico. No entanto o vídeo mostra as dificuldades de um personagem obeso, de auto-aceitação (ele fica triste, chora) e de dificuldades com vestimenta (o botão da calça estoura e a calça cai). Através da prática corporal (caminhada) o personagem consegue emagrecer e se torna um vitorioso. Fica subentendido que só pode ser vitorioso quem é magro ou está dentro do padrão estético corporal. De acordo com Luz (2007):

No universo simbólico da cultura contemporânea há um conjunto de representações relativas aos valores dominantes na sociedade, como o individualismo (...), a competição entre os indivíduos (...), e o consumismo, entendendo-se por este termo a disposição dos indivíduos para adquirir bens materiais ou simbólicos que possam diferenciá-los hierarquicamente como objetivo do viver, o cuidado do corpo como unidade central (e muitas vezes a única) delimitadora do indivíduo em relação aos outros, bem como estratégias de valorização deste corpo para obter, a partir dele, dinheiro, status e poder.

No entanto, nenhum dos comentaristas se atentou para esta leitura do vídeo. Jhony comenta que o vídeo ficou muito convincente e que o mesmo irá comprar seu material esportivo, pois a Olympikus resolveu seu problema. Fica subentendido aqui no seu discurso que o problema que ele se refere é a obesidade, pois a propaganda destaca 
que praticando caminhada a pessoa emagrece. Porém, seu discurso tem um tom irônico. De acordo com Maingueneau (2002, p. 175), "a enunciação irônica apresenta a particularidade de desqualificar a si mesma, de se subverter no instante mesmo em que é proferida".

A seguir a descrição do vídeo "Buscando resposta", vencedor da categoria júri popular.

Vídeo "Buscando respostas" - 1'36" - Direção e roteiro Lucas Bottaro, produção Parkour Araçatuba

O vídeo apresenta jovens praticantes de Parkour na cidade e na natureza. Uma voz em off diz: “Para que serve tanta dedicação? Se eu estou treinando sempre de trás das cortinas. Tentando ser preciso em meus objetivos. Buscando ser forte para poder ser útil. Enfrentando meus medos, desde os movimentos mais simples, até o mais complexo. Descobri que eu sou livre, livre para manter o equilíbrio entre a natureza e o homem. Ajudar os meus amigos, escolher o meu próprio caminho e me sentir bem". INSPIRE-SE

Este vídeo gerou 13 comentários, destacamos quatro para análise.

rafa - 09/10/2009 12:00:13

O video é bom, mas a locução é péssima, imagine que o resto do Brasil tem PAVOR desse sotaque de Barbacena.

\section{Lucas Bottaro - 10/10/2009 10:57:05}

heheheheh a locução não tem jeito, foi a parte mais demorada pra fazer, eu gravei e regravei mil vezes, mas não tem jeito, e não tem pra quem pedir tambem ia sair tudo igual eu.

\section{Epix - 14/10/2009 11:03:28}

Boa Lucas! A narração, uma das partes primordiais do seu vídeo, realmente deixou a desejar. Dava pra pagar pra alguém fazer, moço, não é caro. MAS, parabéns de qualquer modo. Ah, a mistura das imagens de duas cams também deixou o vídeo sem padrão, mas isso é o de menos. ;-)

\section{luiz - 24/11/2009 07:12:03}

pela proposta do concurso fez bem, menos pela voz mas a mensagem é lega, inspiradora e com bons pulosl!

A maioria dos comentários se refere não ao conteúdo do vídeo e sim a sua forma, os internautas questionam, sobretudo, a qualidade da locução. Rafa é preconceituoso em relação ao sotaque interiorano do locutor, faz uma generalização de que o Brasil tem pavor deste tipo de linguajar, situando seu discurso numa perspectiva "urbanocêntrica" de cultura, desprezando a cultura 
das pessoas que moram no interior ou meio rural. Lucas, o diretor do vídeo se explica, diz que tentou melhorar a locução, mas não conseguiu. Epix sugere a Lucas que ele pague alguém para fazer locução e comenta que as imagens gravadas por duas câmeras deixaram o vídeo sem padrão. Termina dizendo que os detalhes técnicos são de menos, ficando subentendido que não tiram o mérito do vídeo. Luiz comenta que o vídeo foi bem feito dentro da proposta do festival, exceto a locução. Elogia os saltos dos praticantes de Parkour e diz que a mensagem é inspiradora. Os quatro comentários fazem uma leitura negociada do vídeo de acordo com a proposta de Hall (2006).

A seguir a descrição do vídeo "Cicloturismo", segundo colocado no júri técnico.

Vídeo Inspire-se Cicloturismo 1'10" - Direção, roteiro e produção Daniel Rodrigues

O vídeo mostra imagens de um ciclista pedalando nas ruas da cidade de noite e depois amanhecendo o dia na beira de uma rodovia. A música de fundo e a voz em off é da propaganda "Inspire-se" da Olympikus. Voz em off: "Por quê? Se não há medalhas nem troféus. Se não tem torcidas nem aplausos nem hinos de vitória, só o silêncio. Por que então? Se não há dinheiro e nem contratos, se não tem flashes, câmeras nem pódios, nem glórias, talvez só uma luz. Onde estão as pistas, os campos, as quadras, os estádios? Onde estão os adversários, os rivais, onde está o tempo?" Inspirese. "O limite, onde está o limite?" INSPIRE-SE

Este vídeo ocasionou 21 comentários. A seguir alguns deles:

will... - 22/09/2009 03:38:00

a redação está perfeita, pena que ela já existe...

Emanuel Duarte - 22/09/2009 05:50:49

muito boa a sua releitura!

\section{Samuel - 22/09/2009}

\section{7:59:44}

Pô! esse foi o vídeo que aumentou mais rápido as visualizações. a divulgação deve ser boa, ou...

\section{william - 22/09/2009 08:01:56}

de 23 para 239 visualizacoes em menos de 3 horas é algo beeem estranho...

\section{Samuel}

22/09/2009 08:04:57

já ouviram falar em varredura de IP? ou vale tudo?

\section{Daniel}

23/09/2009 08:19:04

já ouviram falar de divulgação em comunidade, msn, orkut, amigos, família, cachorro, papagaio, pessoas estranhas, academia onde trabalho, escrever na testa, na camiseta, na bicicleta????? 
Will comenta que a redação da mensagem é perfeita, mas que já existe. Ficando subentendido que não houve criatividade em relação à mensagem do vídeo. Emanuel elogia o vídeo, dizendo que foi boa a releitura, uma vez que o mesmo se inspirou em uma propaganda da Olympikus que circulou nas TVs em 2009, chamada "Inspire-se". Deste modo, o vídeo dialoga com a propaganda citada. Conforme Maingueneau (2002), um discurso pode imitar outro através de duas estratégias opostas: a captação e a subversão. A captação é quando um texto imita outro, tomando a mesma direção. Já a subversão ocorre quando o texto que imita tenta desqualificar o texto imitado, realizando uma paródia. No que tange a mensagem do vídeo, podemos dizer que ela apresenta estilo de discurso filosófico, uma vez que questiona os motivos que levam as pessoas a realizarem a prática corporal, mas não dá as resposta diretamente. No entanto, elimina por negação, as possibilidades de motivação relacionadas a prêmios no esporte ou dinheiro e contratos de trabalho.

Os quatro últimos comentários dizem respeito ao número de visualizações que o vídeo recebeu. Samuel constata que as visualizações deste vídeo aumentaram com muita rapidez, sugere que a divul- gação é boa. William questiona o alto número das visualizações em pouco tempo. Samuel complementa o questionamento levantando a hipótese de varredura de IP, interroga se vale qualquer estratégia para aumentar o número de visualizações. Daniel, o diretor do vídeo explica que ele divulgou o vídeo em comunidades, MSN, Orkut, amigos, família, local de trabalho. Ele dialoga com os dois comentários anteriores, apresenta um tom irônico ao dizer que divulgou seu vídeo para cachorro, papagaio, escreveu na testa! Podemos pressupor que a estratégia da Olympikus para reforçar sua marca teve efeito, pois os diretores dos vídeos divulgaram suas produções amplamente, inclusive em comunidades virtuais como MSN e Orkut.

\section{Considerações Finais}

Através da análise pudemos constar grande diversidade de práticas corporais presentes nos vídeos do festival, totalizando trinta e oito práticas corporais diferentes, as mais presentes foram a corrida, o futebol e o skate. Em relação aos significados relacionados às práticas corporais, pudemos constatar também uma variedade de temas/ significados expressos nas mensagens dos vídeos. Identificamos vinte e oito temas relacionados às práticas 
corporais, os mais frequentes foram: a realização de práticas corporais servindo de inspiração para as mesmas; persistência, superação de limites e das adversidades; e cotidiano das pessoas e suas relações com as práticas corporais.

Em relação ao processo de recepção/interação sobre os vídeos, constatamos nos comentários diálogos que criticam, congratulam, sugerem, questionam os vídeos. Estes comentários versavam sobre o conteúdo dos vídeos, mas também sobre a forma (recursos técnicos) em que os mesmos foram realizados. No que tange ao processo de decodificação segundo a proposta de Hall, a maioria dos comentários se situaram num código dominante (leitura consensual) ou negociado (leitura que concorda com parte do conteúdo e questiona outra parte, mas sem fazer referência ao sistema social), apenas um comentário fez uma leitura oposicionista, questionando a competição e o próprio sistema capitalista, através de seus valores (competição, ter em detrimento do ser).

A Olympikus, através do festival OLYMPIKUS.MOV esta utilizando os novos recursos da Web 2.0., realizando uma comunicação com os consumidores, tendo a sua marca como suporte e veículo de interação entre empresa e mercado. Além de pretender que os consumidores comprem seus produtos, está organizando-os em torno de sua marca. Por um lado, o festival é interessante por destacar o potencial criativo do público relacionado aos discursos sobre as práticas corporais -, tornando-os receptores mais ativos, produtores de mídia e capazes de expressar sua opinião. Por outro, explora o potencial de marketing digital interativo, recrutando publicitários potenciais - amadores ou não -, para reforçar a sua marca e propagandeá-la no ambiente virtual.

\section{Referências}

BAKHTIN, M. Marxismo e Filosofia da Linguagem: problemas fundamentais do método sociológico na ciência da linguagem. Trad. Michel Lahud et. al. $8^{\text {a }}$ ed. São Paulo: Hucitec, 1997.

. Estética da criação verbal. Trad. Paulo Bezerra. 4 ed. São Paulo: Martins Fontes, 2003.

BELLONI, M. L. O que é mídiaeducação. 3 ed. rev. CampinasSP: Autores Associados, 2009.

BETTI, M. Educação Física e Sociologia: novas e velhas questões no contexto brasileiro. CARVALHO, Y. M. de.; RUBIO, K. (orgs.). Educação Física e Ciências Humanas. São Paulo: Hucitec, 2001, p. 155-169. 
Educação Física Escolar:

ensino e pesquisa-ação. Ijuí-RS: EdUnijuí, 2009.

CARVALHO, Y. M. de. Promoção da Saúde, práticas corporais e atenção básica. Revista Brasileira de Saúde da Família. v. 7, n. 11, p. 33-45, jul-set. 2006.

COSTA, R. R. da. A "dança" dos gêneros audiovisuais na convergência das mídias: um estudo de migrações e transmutações na Web. 2.0. III Encontro Nacional sobre Hipertexto. Belo Horizonte-MG, p. 01-12, 29 a 31 de outubro de 2009.

COUTINHO, M. Marketing e comunidades digitais: do discurso ao diálogo. Revista da ESPM, v. 14, n. 2, p. 28-39, 2007.

HALL, S. Codificação e decodificação. HALL, S. Da diáspora: identidades e mediações culturais. 1 reimp. rev. Belo Horizonte: EdUFMG, 2006, p. 365-381.

LUZ, M. T. Novos saberes e práticas em saúde coletiva: estudo sobre racionalidades médicas e atividades corporais. 3 ed. São Paulo: Hucitec, 2007.

MAINGUENEAU, D. Análise de textos de comunicação. 2 ed. São Paulo: Cortez, 2002.

MENDES, D. S. et. al. Blogs e blogueiros do Pan 2007: um estudo sobre os jogos no ciberespaço. PIRES, G. De L. (org.). "Observando" o Pan RIO/2007 na mídia. Florianópolis: Tribo da Ilha, 2009, p. 87-112.

OLIVEIRA, R. Convergências midiáticas: três categorias.

Conexões midiáticas: revistas dos alunos de Pós-graduação em Comunicação da UFPB, n. 3, p. 1-10, março a agosto de 2010.

OLYMPIKUS. Olympikus.Mov: Festival online de vídeos. 2009. Disponível em: http://www. olympikusmov.com.br; Acesso em: agosto de 2010.

PIRES, G. De L. Cultura esportiva e mídia: abordagem críticoemancipatória no ensino de graduação em Educação Física. BETTI, M. (org.). Educação Física e mídia: novos olhares, outras práticas. São Paulo: Hucitec, 2003, p. 19-44.

STAM, R. Bakhtin e a crítica midiática. RIBEIRO, A. P. G.; SACRAMENTO, I. (orgs.). Mikhail Bakhtin: linguagem, cultura e mídia. São Carlos-SP: Pedro e João Editores, 2010, p. 331-358.

Recebido: setembro/2010. Aprovado: outubro/2010. 